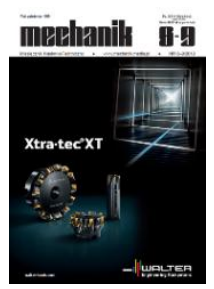

How to cite this article:

Authors: Michał Kończak, Mateusz Kukla, Krzysztof Talaśka

Title of article: „Self-excited vibrations in the off-road machines”

Mechanik, No. 8-9 (2019)

DOI: https://doi.org/10.17814/mechanik.2019.8-9.70

\title{
Self-excited vibrations in the off-road machines
}

\author{
MICHAŁ KOŃCZAK \\ MATEUSZ KUKLA \\ KRZYSZTOF TALAŚKA*
}

Mgr inż. Michał Kończak, konczakmichal@gmail.com, https://orcid.org/0000-0002-0954-2012 - Politechnika Poznańska, Poznań, Polska Dr inż. Mateusz Kukla, mateusz.kukla@put.poznan.pl, https://orcid.org/0000-0003-3456-3824 - Politechnika Poznańska, Poznań, Polska Dr inż. Krzysztof Talaśka, krzysztof.talaska@put.poznan.pl, https://orcid.org/0000-0001-9736-9725 - Politechnika Poznańska, Poznań, Polska

Self-excited vibrations are a source of vibrations and noise that directly affect operators of off-road machines. Minimizing the values of these parameters is beneficial for a number of reasons, among which the health and ecological as well as economic ones should be considered the most important. KEYWORDS: self-excited vibrations, self-excrescence, vibration, noise, off-road machine

\section{Introduction}

In the theory of basic mechanics, physical systems that characteristics of which are not variable in time or change very slowly are called autonomous systems [1]. The omission of slow changes as a function of time cannot result in a significant error value.

A special, noteworthy case is self-excited systems. They belong to the group of autonomous nonconservative systems [1]. They are characterized by the fact that during vibrations, energy losses occur, which are then compensated by an external source, which causes the vibrations to be sustained, and in the extreme case - their increase. They are called self-excited vibrations or self-vibrations [2]. The characteristic feature of self-excited systems is that in the equations describing their oscillatory motion, the time parameter occurs implicitly. The system self-regulates compensation of energy losses, e.g. through a non-linear element, from an external source. It is unchanging in time, therefore it is necessary to have feedback between the vibrating and regulating system. This structure of the system (fig. 1) allows for the occurrence of non-disappearing periodic vibrations, despite energy losses occurring in it.

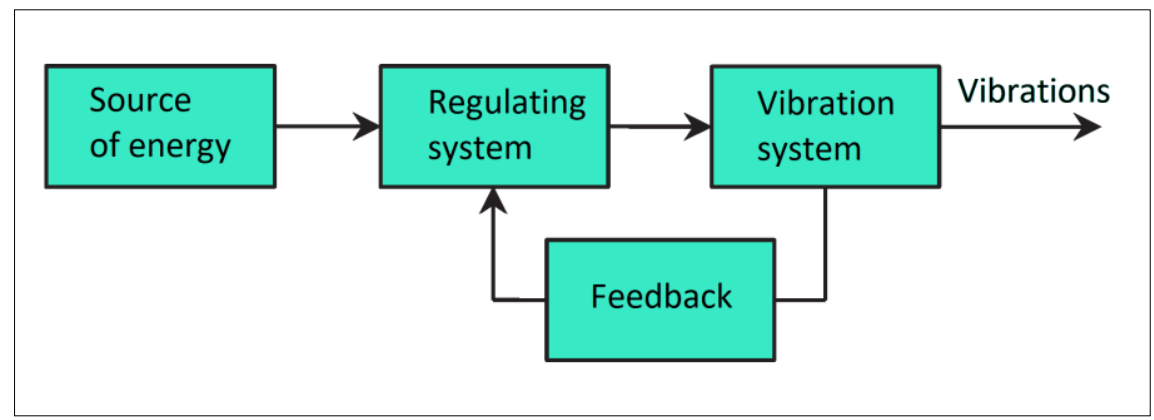

Fig. 1. Block diagram of self-excited system; own study based on [2]

Vibrations often tend to increase until they are fixed, which means they become stationary. This state occurs after a small disruption of the system's operation, leading to an unstable equilibrium position. This situation can be observed during the occurrence of steady vibration when the sum of $E_{\mathrm{R}}$ dissipated energy and $E_{\mathrm{D}}$ supplied energy is balanced. This energy balance is a prerequisite for self-excited vibrations. 
Assuming that the origin of the coordinate system is the point of static equilibrium of the system, the following analysis can be performed. Disturbance of the system results in its oscillating motion. A system characterized by stability should strive to regain balance by dissipating $E_{\mathrm{R}}$ energy. This does not happen, because vibrations are amplified as a result of $E_{\mathrm{D}}$ supplied energy, which is schematically shown in fig. 2. In the first phase of movement, the supplied energy is greater than the dissipated energy, which causes the amplitude to increase to the value $A$. In the second phase, the dissipated energy is greater from supplied energy, which in turn reduces the amplitude. The energy equilibrium of the system is point $R$, which is a kind of balance point for a certain value of amplitude $A$. This system is located in the so-called steady vibration phase, which is called the limiting cycle.

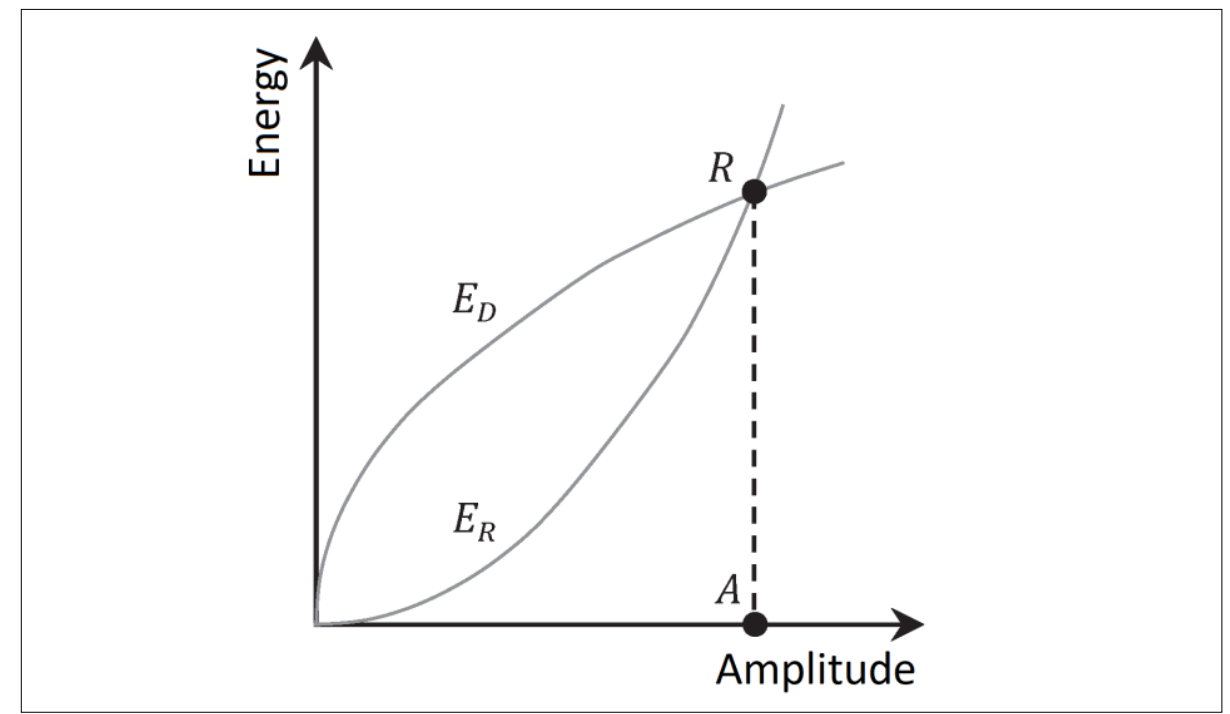

Fig. 2. Energy balance chart of the self-excited system; own study based on [2]

Systems are called quasi-linear if their stationary self-excited vibrations are close to periodic, with the frequency of normal mode of the system. On the other hand, we can indicate vibrational relaxation, which occurs when the established self-excited vibrations differ significantly from the harmonics with the jumps in velocity values [1]. Solution of the equations for determining the self-oscillations is obtained, for example, by van der Pol methods. They determine the energy balance of a given system or structure of elements or bodies. General form of the discussed equation is given by the formula (1):

$$
x_{1}(t)=A(t) \sin \left(\omega_{0} t\right)
$$

where: $t$ - time, $\omega_{0}$ - circular frequency, $x_{1}-$ displacement.

Assuming that the amplitude $A(t)$ changes slowly and its increase by the value of $\Delta A$ during one period is sufficiently small, the speed can be approximately described by relationship (2):

$$
\dot{x}_{1}(t)=A(t) \omega_{0} \cos \left(\omega_{0} t\right)
$$

a)

b)
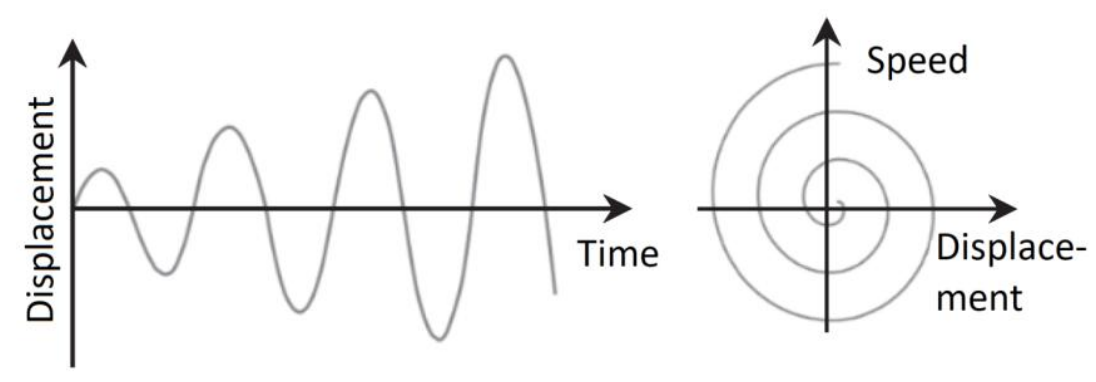

Fig. 3. Characteristics obtained from the van der Pol equations: $a$ ) process of vibrations excitation, b) course of phase trajectories; own study based on [1] 
Another method of describing the self-excited vibrations is the Rayleigh equation, which can be achieved from the van der Pole equation. Its general form is given by relationship (3):

$$
\ddot{x}(t)-\mu\left(\dot{x}-\frac{\dot{x}^{3}}{3}\right)+x=0
$$

where: $\ddot{x}$ - acceleration of vibrations, $\mu$ - parameter responsible for non-linearity and attenuation.

To illustrate this equation, one can use the Lienard method, in which the curve will change depending on the parameter $\mu$. The lower the value of this parameter, the closer the phase curve is to the circle, while the higher - the more it deforms along the $x$ axis, as shown in fig. 4. The equation of phase trajectories takes the form of the relationship (4):

where the Lienard curve is described as:

$$
\frac{\mathrm{d} u}{\mathrm{~d} x}=\frac{\mu\left(u-\frac{u^{3}}{3}\right)-x}{u}
$$

where: $x, u$-phase coordinates.

$$
x=\mu\left(u-\frac{u^{3}}{3}\right)
$$

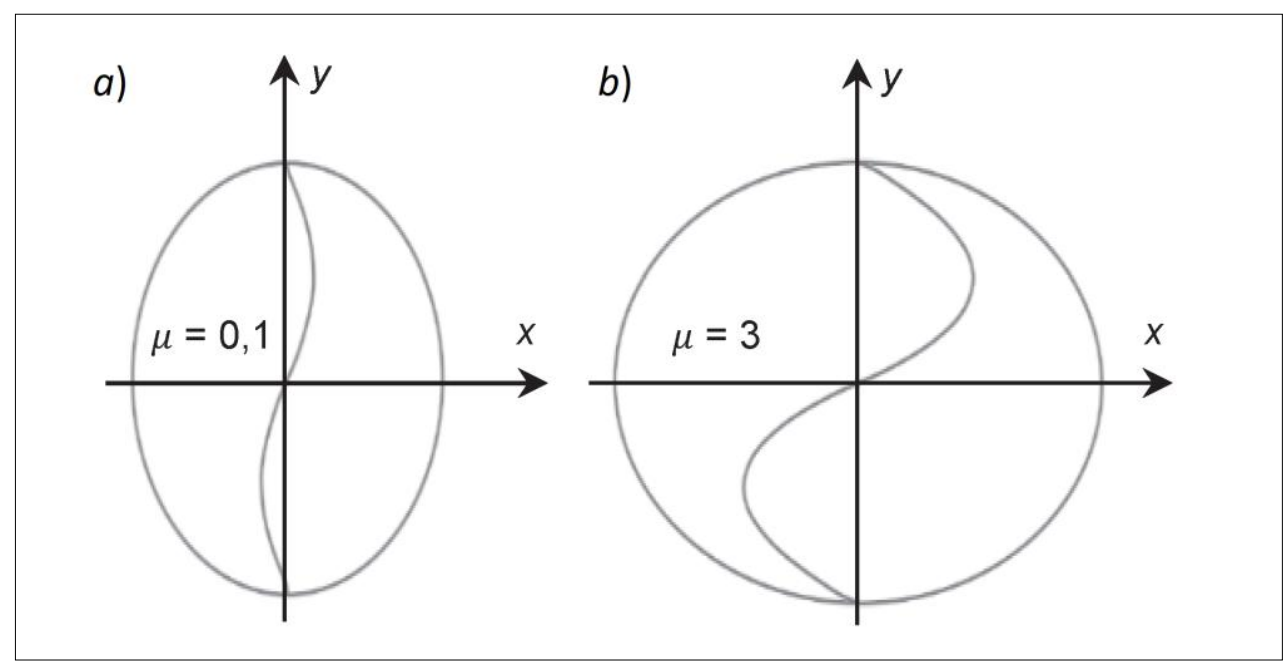

Fig. 4. Lienard curves for various values of parameter $\mu$; own study based on [3]

In everyday life, one can often encounter self-excited vibrations. Common examples of this phenomenon include speech, bird chirping, leaf tremor, and others related to the occurrence of dry friction, such as the creaking of a door or playing a string instrument.

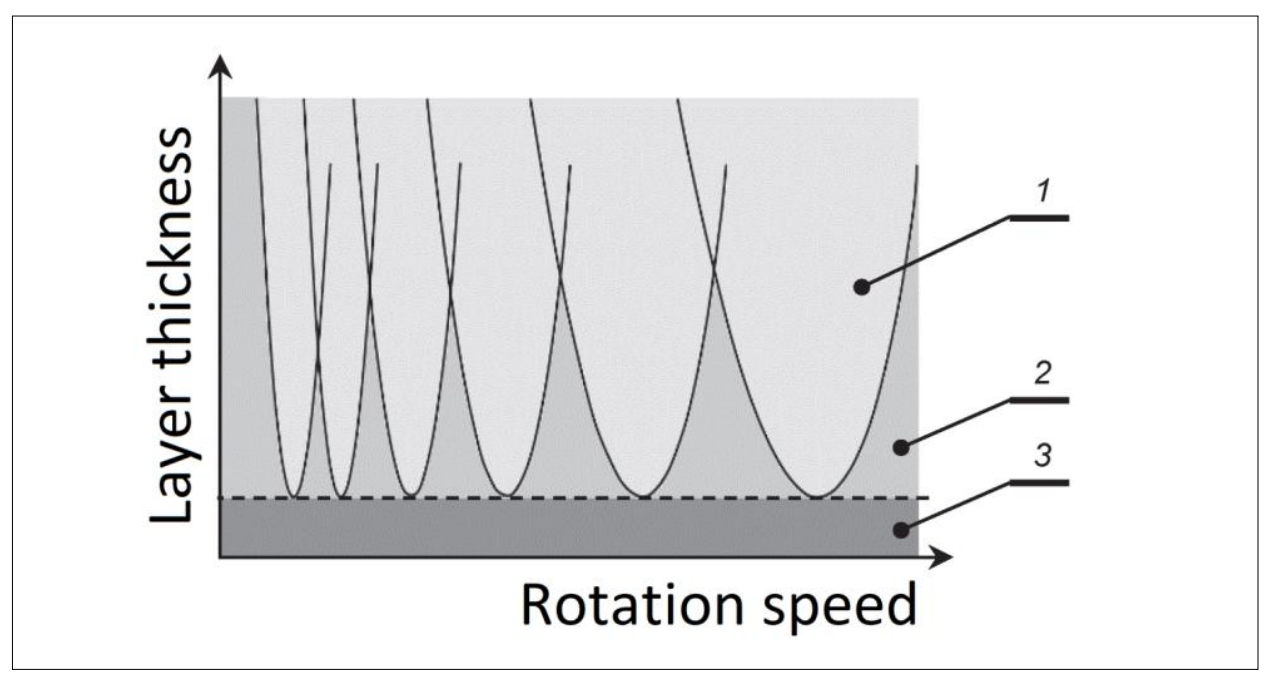

Fig. 5. Machining characteristics - bag curves; 1 - unstable machining area, 2 - stable machining area, 3 - stable machining area over the entire rotational speed range; own study based on [5] 
In technique, this type of vibration is very common and is an important issue. Self-excited systems are intentionally used, e.g. in electronics, where amplifiers can be considered a classic example of this type. On the other hand, their negative effects can be observed, among others, during the occurrence of dry friction, vibrations of the tool during machining, galloping of power networks, shaking of mirrors in cars during low engine revolutions and vibrations of suspension bridges [1]. Sometimes the occurrence of self-excited vibrations is dangerous and their elimination is necessary. In aviation, self-shaking can lead to a phenomenon called the plane's wing flatter, and ultimately to a catastrophe.

Currently, the technique of vibration reduction is an important issue due to the strength and durability of the structure and user safety. Exceeding the assumed safe level of vibration amplitude may cause material fatigue and lead to its destruction, as in the case of thin-walled materials or welded joints. Vibrations can also cause elements of the system to move relative to each other leading to their leakage. Otherwise, the mechanisms may jam or the fasteners may become loose, which is crucial for the safety of the rotating machine operator. Increasing machining parameters to improve performance often causes the tool system to be out of balance. This is important for tool durability and surface quality. The characteristics of this process are shown in fig. 5.

\section{Review of the technology status}

Vibration reduction is also important due to the ergonomics of machine use. Until now, attention has been focused on the generated noise, which is troublesome for the user even after short-term operation and significantly affects the decrease in performance. In addition, in the last two decades, there have been issues related to the occurrence of vibrational disease. It is extremely dangerous and may cause carpal tunnel syndrome, joint degeneration, polyneuritis, lowering or increasing blood pressure, Raynaud's symptoms or even amputation of fingers or whole hands due to destruction of the vascular system of hands [6]. For this reason, it is important to prevent the occurrence of self-excited vibrations or to minimize their negative effects.

Level of permissible noise and vibration transmitted by machines was regulated by standards that were included in the provisions of the Labor Code [7]. The most important standards include:

- regulation of the Minister of Economy and Labor of 5 August 2005 on occupational health and safety at work related to exposure to noise or mechanical vibrations [Rozporządzenie Ministra Gospodarki i Pracy z dnia 5 sierpnia 2005 r. w sprawie bezpieczeństwa i higieny pracy przy pracach związanych z narażeniem na hałas lub drgania mechaniczne] Uournal of Laws of the Republic of Poland - Dz.U. 2005 No. 157 item 1318) - specifies the maximum permissible volume of noise and vibrations in the work environment,

- regulation of the Minister of Family, Labor and Social Policy of June 12, 2018 regarding the highest allowable concentrations and intensities of factors harmful to health in the work environment [Rozporządzenie Ministra Rodziny, Pracy i Polityki Społecznej z dnia 12 czerwca 2018 r. w sprawie najwyższych dopuszczalnych stężeń i natężeń czynników szkodliwych dla zdrowia w środowisku pracy] (Uournal of Laws of the Republic of Poland - Dz.U. 2018, item 1286),

- PN-ISO 1999:2000 - Acoustics - Determination of occupational noise exposure and estimation of noiseinduced hearing impairment [Akustyka - Wyznaczanie ekspozycji zawodowej na hałas i szacowanie uszkodzenia słuchu wywołanego hałasem] - determines the permissible exposure to noise during eighthour work for five working days a week,

- PN-N-01352: 1991 - Vibration - Rules of making measurements at work places [Drgania - Zasady wykonywania pomiarów na stanowiskach pracy] - describes the impact of vibrations without interruption during an eight-hour shift.

For example: on the basis of these standards, $125 \mathrm{~dB}$ was determined as the noise limit for machines constituting an energy source (engines), and $99 \mathrm{~dB}$ for wood saws, assuming that a given machine is the main source of noise at the workplace. Therefore, to be more competitive, machine manufacturers had to take into account the phenomenon of self-excited vibration and to deal with related problems.

As a result of own research on the current state of technology, data on selected off-road machines was collected. Their summary is presented in the table.

Analysis of the published data allows to notice significant differences in both the vibration volume and the noise level. They result from many factors. It is worth noting that the standards allow certain ranges of these values depending on their duration during operation. The level of noise acting on the organ of hearing can be determined using the principle of equal energy. It assumes the occurrence of the same potential effects for humans at different values of energy and time of its impact. For example, in relation to the noise level, the equivalent values are: $85 \mathrm{~dB}$ for 8 hours, $88 \mathrm{~dB}$ for 4 hours, $91 \mathrm{~dB}$ for 2 hours, $94 \mathrm{~dB}$ for 1 hour and $97 \mathrm{~dB}$ for 
30 minutes [8]. However, the use of this method raises some doubts [8]. On the other hand, it provides the basis for determining and assessing the theoretical times in which one can work with the devices listed in the table.

TABLE. Data set for selected off-road machines

\begin{tabular}{|c|c|c|c|c|c|}
\hline Machine & Drive type & Source of energy & $\begin{array}{c}\text { Sound power } \\
\text { level }{ }^{1} / \text { Noise } \\
\text { level }^{2} \\
{[\mathrm{~dB}]}\end{array}$ & $\begin{array}{l}\text { Generated } \\
\text { vibration for the } \\
\text { main / } \\
\text { additional } \\
\text { handle* } \\
{\left[\mathrm{m} / \mathrm{s}^{2}\right]}\end{array}$ & Manufacturer \\
\hline $\begin{array}{l}\text { Lawn mower } \\
756 \text { YS }\end{array}$ & $\begin{array}{l}\text { hydrostatic } \\
\text { transmission }\end{array}$ & $\begin{array}{c}\text { diesel engine } \\
179 \mathrm{~cm}^{3}\end{array}$ & $98^{2}$ & $2.4 / 1.2^{*}$ & Stihl \\
\hline $\begin{array}{c}\text { Wood splitter } \\
6422\end{array}$ & hydraulic & $\begin{array}{c}\text { diesel engine } \\
208 \mathrm{~cm}^{3}\end{array}$ & $94.1^{2}$ & - & Hecht \\
\hline $\begin{array}{l}\text { Wood splitter } \\
\text { ZI HS10TN }\end{array}$ & hydraulic & $\begin{array}{c}\text { electric engine } \\
3 \mathrm{~kW}\end{array}$ & $80^{2}$ & 2.5 & Zipper \\
\hline $\begin{array}{l}\text { Wood splitter } \\
\text { LS05V }\end{array}$ & hydraulic & $\begin{array}{c}\text { electric engine } \\
5.1 \mathrm{~kW}\end{array}$ & $75^{2}$ & 2.5 & Cedrus \\
\hline $\begin{array}{l}\text { Wood splitter } \\
\text { LS07V }\end{array}$ & hydraulic & $\begin{array}{c}\text { electric engine } \\
3.5 \mathrm{~kW}\end{array}$ & $83.6^{2}$ & 2.5 & Cedrus \\
\hline Chainsaw 440 & chain & $\begin{array}{c}\text { diesel engine } \\
40.9 \mathrm{~cm}^{3}\end{array}$ & $112^{1}$ & $3.8 / 4.2^{*}$ & Husqvarna \\
\hline Chainsaw 555 & chain & $\begin{array}{c}\text { diesel engine } \\
59.8 \mathrm{~cm}^{3}\end{array}$ & $116^{1}$ & $3.5 / 5^{*}$ & Husqvarna \\
\hline $\begin{array}{l}\text { Chainsaw } \\
\text { MS } 211\end{array}$ & chain & $\begin{array}{c}\text { diesel engine } \\
35.2 \mathrm{~cm}^{3}\end{array}$ & $113^{1}$ & 3.5 & Stihl \\
\hline $\begin{array}{l}\text { Chainsaw } \\
\text { MS } 362\end{array}$ & chain & $\begin{array}{c}\text { diesel engine } \\
59 \mathrm{~cm}^{3}\end{array}$ & $117^{1}$ & 3.5 & Stihl \\
\hline $\begin{array}{l}\text { Chainsaw } \\
\text { SP } 426\end{array}$ & chain & $\begin{array}{l}\text { diesel engine } \\
42.4 \mathrm{~cm}^{3}\end{array}$ & $114^{1}$ & $5.93 / 5.4^{*}$ & Stiga \\
\hline
\end{tabular}

\section{Summary}

Unintentional self-excited vibrations in machines are an undesirable phenomenon that can result in a significant reduction in system life, but also in sudden, permanent damage.

Elimination of vibrations is also necessary from the point of view of ergonomics of use and increasing employee efficiency by extending the possible working time and at the same time, reducing the psychophysical load. Machine manufacturers are required to meet standards regarding vibration and noise. However, method of their detection and elimination is often a complicated process, that rises costs, which translates into the price of the product.

Therefore, it is reasonable to undertake research work focused on determining the processes of self-excited vibration. This will enable the development of measurement methodologies related to determining the level of vibration, but also the amount of sound pressure. The effects of these works will be basis for modeling the executive systems of off-road machines that generate self-excited vibrations. Due to this, it will be possible to analyze them. The purpose of the work being carried out is to define the parameters and guidelines, the inclusion of which in the structure will result in the reduction of adverse phenomena related to the occurrence of mechanical vibrations and noise. 


\section{REFERENCES}

[1] Giergiel J. „Drgania mechaniczne”. Kraków: Wydawnictwo AGH, 2000. ISBN 83-88408-80-1.

[2] Arczewski K., Pietrucha J., Szuster J.T. „Drgania układów fizycznych”. Warszawa: Oficyna Wydawnicza PW, 2014. ISBN 978-83-7814-246-1.

[3] Osiński Z. „Teoria drgań”. Warszawa: Państwowe Wydawnictwo Naukowe, 1980. ISBN 83-01-02278-7.

[4] Osiński Z. „Tłumienie drgań”. Warszawa: Państwowe Wydawnictwo Naukowe, 1997. ISBN 83-01-124040 .

[5] Morek R. „Obróbka stabilna - drgania samowzbudne”. TeWy. 6 (2015): 1-5.

[6] Szczeklik A., Gajewski P. „Interna Szczeklika”. Medycyna Praktyczna, Kraków 2018. ISBN 978-83-7430549-5.

[7] Dziurdź J. „Zagrożenia człowieka w środowisku pracy. Drgania i hałas. Materiały dydaktyczne”. Warszawa: Politechnika Warszawska, 2011.

[8] Pawlaczyk-Łuszczyńska M. (red.) „Minimalizowanie ryzyka uszkodzenia słuchu w miejscu pracy - poradnik dla pracowników BHP, PIS, PIP, pracodawców i pracowników". Łódź: Oficyna Wydawnicza Instytutu Medycyny Pracy im. prof. J. Nofera, 2010, ISBN 978-83-60818-49-7.

[9] Szulewski P., Śniegulska-Grądzka D. „Systemy automatycznego pomiaru drgań w obrabiarkach”. Mechanik. 3 (2017): 170-175.

[10]Katedra Dynamiki Maszyn. „Pomiar parametrów drgań. Materiały dydaktyczne”. Łódź: Politechnika Łódzka. Online: http://www.kdm.p.lodz.pl/wyklady/lab/cwiczenie1.pdf (access: 21.03.19). 